\title{
МОНГОЛ ДАХЬ ОРОС СУДЛАЛ
}

Д.Алтай

ОУСХ ийн Эрдэм иинжилгээний ахлах ажилтан, доктор (PhD), профессор Цахим иуудан: tbishrel@yahoo.com

ШУА-ийн Олон Улс Судлалын Хүрээлэнд /цаашид ОУСХ/ Орос судлал бие даасан салбарын хувьд 2000 оноос төлөвшин хөгжиж байна. Энэ салбарыг шинжлэх ухааны доктор, Төрийн соёрхолт О.Батсайхан тэргүүлдэг ба энд нийт 9 судлаач ажилладаг. Орос судлалын салбарын онцлог нь Орос орны түүх, өнөөдрийн байдлыг бодитоор судлахдаа орон судлалын чиглэлтэй хослуулах, гадаад бодлого болон олон улсын харилцаанд ОХУ-ын үзүүлэх нөлөөг цогц байдлаар судалдагт оршдог. Судалгааны үндсэн чиглэлд ОХУ ын дотоод, гадаад бодлогын тулгамдсан асуудлууд, МонголОросын харилцаа, түүний түүх, өнөөгийн байдал, ирээдүйн хандлага, даяаршилын эрин үе дэх Орос орны хөгжлийн стратегийн асуудлууд ордог.

90-ээд оноос өмнө Зөвлөлт судлал түүн дотроо Монгол-Зөвлөлтийн харилцаа, нийгэм-улс төрийн хүрээний асуудлыг Намын ТХ-ны дэргэдэх Намын түүхийн Институтэд / хожим Нийгмийн Ухааны Институт/ голлон судалдаг байсан бол иргэний түүхийн сэдвээрхи судалгаа нь ШУА ийн Түүхийн Хүрээлэн, Дорно дахины судлалын Хүрээлэнд /өнөөгийн ОУСХ/ төвлөрч ЗХУ, БНХАУ гэсэн хоёр хөрш орон судлал, Монгол Улсын гадаад бодлого, олон улсын байдлын тулгамдсан асуудлууд, БНМАУ-ын капиталист бус хөгжлийн зам, "гуравдахь ертөнцийн” орнуудыг судлах чиглэлд түлхүҮ хийгдэж байв. Энэ үеийн ЗХУ-ыг судлах үндсэн чиглэлд:

-1905-1907 оны Оросын хувьсгал, 1917 оны Октябрийн хувьсгал ба түүний Дорно дахинд ялангуяа Монголд нөлөөлсөн асуудал
-БНМАУ ба ЗСБНХУ ын хоорондын aх дүүгийн найрамдалт харилцаа, МонголЗөвлөлтийн хамтын ажиллагаанд МАХН, ЗХУКН Ын гүйцэтгэсэн үүрэг роль

-Монгол-Зөвлөлтийн харилцааны түүх, хөгжлийн үе шат, 2 орны хоорондын соёл- шинжлэх ухааны харилцааны өрнөлт

- ЗХУКНамын их хурал, ТХ ны бүгд

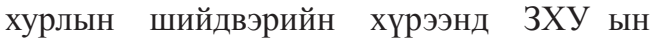
гадаад, дотоод бодлогын үндсэн зорилтууд

-ЗКУКН-ын их хурал, ТХ-ны бүгд хурлуудын баримт бичгийг монгол хэлнээ хөрвүүлж. хэвлэн гаргах зэрэг асуудал багтаж байв.

Үүнээс харахад судалгааны чиглэл нь улс төрийн агуулгаар тодорхойлогдож, ертөнцийг Үзэх марксист-ленинист үзэлд тулгуурлаж байсан нь тодорхой . Тиймээс ч тухайн цаг үеийн үзэл сурталд баригдсан нэгдмэл байр суурь, хандлагыг илэрхийлж байв. Манай ахмад үеийн олон түүхчид дээрх чиглэлээр судалгааны олон ном зохиол туурвисан ба тэдгээрийн агуулга, ач холбогдлыг эдүгээ бүхэлд нь үгүйсгэх аргагүй, харин ч эдгээр бүтээл бидний өнгөрсөн үеийн түүхэн илэрхийлэл болж байдаг. ЗХУ-ыг судлах асуудал “үзэл санаа нэгтэй” ахдаа хандаж байгаa онцгой харилцаагаар тодорхойлогдож, उХУ нь Монгол орны хувьд үлгэр дууриал, социалист хамтын нөхөрлөлийн манлайлагч улс байсан төдийгүй БНМАУ-ын нийгмийн амьдралын бүхий л хүрээнд туслалцаа дэмжлэг үзүүлдэг дотны холбоотон байлаа. Зөвлөлт судлалын судалгаа ихэвчлэн 2 талын харилцаа, хамтын ажиллагаа болон ЗСБНХУ Монголд ах дүҮ ёсны тусламж үзүүлсэний үр дүн зэрэг цөөн асуудлаар хязгаарлагдаж, 
харин цогц бодитой судалгаа орхигдож байсан талтай. Учир нь энэ цаг үед шинжилгээ судалгаа нь албан ёсны үзэл суртлаар тэтгэгдэн дэмжигдэж байсан тул үүнд зохицсон судалгаа хийгдэж түүний үр дүн болсон ном бүтээл гарч байв.

60-аад оны эхэн үеэс монголын сэхээтний зарим төлөөлөл Монгол Улс нь социализм байгуулах зорилтыг дэвшүүлэн хэрэгжүүлэхдээ хэтэрхий даган дууриаж, өөрийн орны хөгжлийн онцлогийг үл харгалзан Зөвлөлт нийгэмд хэрэгжүүлж буй нийгэмэдийн засгийн зорилтыг шууд хуулбарлаж байна гэсэн санааг илэрхийлэх болсон. ЭнэхүҮ шүүмжлэлийг намын удирдлагууд намын эсрэг байр суурь, “сэхээтний төөрөгдөл” гэж нэрлэн тэдгээр хүмүүсийг албан тушаалаас нь чөлөөлж, нутаг заан явуулах зэрэг шийтгэл ногдуулжээ. Монгол орон нь сталинизмын гашуун ул мөрийг өөрийн түүхэндээ туулж өнгөрүүлсэн.Тухайлбал, нэг хүнийг тахин шүтэх явдлын хор уршиг, олон мянган гэм зэмгүй лам, нам, төрийн удирдах зүтгэлтнүүд, цэргийн дарга нар, тэргүүний сэхээтний төлөөлөгчдийг хэлмэгдүүлсэн явдал зэргийг дурьдаж болно.

Тиймээс ч зөвшөөрөгдсөн үзэл суртлын зарчмын хүрээнд л судалгаа шинжилгээний ажил хийгдэх ёстой гэсэн ойлголт судлаачдын дунд хэвшиж тогтсон байв.

Ардчилал, зах зээлийн харилцаанд шилжих болсноор нийгмийн ухамсарт түүхийн үйл явцыг харуулахдаа тогтсон үзэл сурталжсан хандлагаас аажмаар татгалзах болсон. Нийгмийн шинжлэх ухааны хөгжилд шинэ үе хэлж, түүхийн асуудлыг бодитой, олон талт дүн шинжилгээ хийх орчин үеийн арга зүйд тулгуурлан хийх эхлэл тавигдав. 90-ээд оны дундуур өмнө нь судлаачдад хаалттай байсан Монгол-Оросын харилцааны асуудлыг хөндсөн архивын олон чухал баримт бичгүүдийг Оросын тал монголын архивд шилжүүлэв. 1990-ээд оноос эдүгээгийн ОУСХ-ийн эрдэмтэд ОХУ-д амьдарч байсан монгол хэл, соёлт үндэстний түүх, Монгол-Орос, Монгол-Хятадын харилцаа, ОХУ-ын Ази, Номхон далайн бүсэд баримтлах гадаад бодлого зэрэг асуудлаар судалгаа хийж, төсөл хэрэгжүүлжээ. Эдгээрийн үр дүнд товхимол $1 /$, нэг сэдэвт зохиол $2 /$ хэвлэгдсэн ба тэдгээрт судалгааны шинэ хандлагын эрэлхийлэл тодорхой ажиглагддаг. Монгол-Оросын хоорондын харилцааны асуудалд шинэ чиглэл болох ОХУ-ын бүс нутгийн хөгжлийн асуудлаар хамтарсан бүтээл 3/ гарсныг энд тэмдэглэх хэрэгтэй. Мөн энэ үед хэвлэгдэн гарсан хэд хэдэн судлаачдын нэг сэдэвт зохиол бүтээлд 4/ Монголын улс төрийн бодлогод олон улсын гадаад орчин ямар нөлөө үзүүлж байсныг цогц байдлаар авч үзэх дүн шинжилгээ хийгдсэн нь олзуурхууштай. Тухайлбал, Монгол Улсын бүрэн эрхт байдал, тусгаар тогтнолын асуудлаар Орос, Хятадын хандлага, байр суурь хэрхэн өөрчлөгдсөнийг задлан нягталсан нь сонирхол татахуйц байв.

Дээр дурьдсан бүтээлийн сацуу олон тооны эрдэм шинжилгээний өгүүллүүд ОУСХ-ийн “Дорно дахины асуудал”, "Өрнө - Баруун”, "Зүүн Хойд Азийн судлал”, “Олон Улс Судлал” нэртэй сэтгүүлүүдэд хэвлэгдсэн байдаг. Эдгээрт Орос судлалын “хаалттай” буюу бага судлагдсан асуудлыг хөндсөн, зарим шинэ чиглэл, сэдвийг гаргаж тавьснаар сонирхолтой байв. Тухайлбал, монголоросын эдийн засгийн хамтын ажиллагаа, монгол -оросын харилцааны түүх, түүний үе шат /энд архивын өмнө хаалттай байсан материалыг ашигласан/, сталинизм ба сүм хийдийн асуудал, монгол-тувагийн хамгийн эмзэг асуудал гэх зэрэг олон сэдвийг дурьдаж болно.

2006 оноос ОУСХ-ийн Орос судлалын салбар “Эв мод” /”Древо единства”/ тусгай сэтгүүлийн хэд хэдэн дугаарыг гаргасан байна. Үүнд танин мэдэхүйн болон эрдэм шинжилгээний шинжтэй өгүүллүүд гарч 
байсан.

2012 онд ОУСХ ийн дэргэд Төв болон Зүүн Европ судлалын Монголын Холбоо ТББ байгуулагдаж дэлхийн ижил нэртэй Олон Улсын Холбоонд / ICCEES/ 2013 онд гишүүнээр элсэж, энэхүY байгууллагын шугамаар Японы Осака хотноо зохион байгуулагдсан Зүүн Азийн Слав болон Еврази судлалын олон улсын 5 дугаар бага хуралд оролцож илтгэл мэдээлэл хэлэлцүүлсэн. ICCEES байгууллага 5 жил тутам дэлхийн Төв болон Зүүн Европ судлалын их хурал, жил бүр Зүүн Азийн бага хурлыг зохиодог уламжлалтай ба Монголын Холбоо ирээдүйд эдгээр арга хэмжээнд идэвхтэй оролцох зорилготой байна. Тус Холбоо 2013 оноос "Центральная и Восточная Европа” нэртэй сэтгүүлийг орос, англи хэл дээр гаргаж эхэлсэн. Сэтгүүлийн гол зорилго нь Төв болон Зүүн Европын орнуудын орхигдсон судалгааг сэргээж эрчимжүүлэх, орон судлал, гадаад бодлого, хоёр талын болон олон талын хамтын ажиллагааны асуудлыг судласны үндсэн дээр танин мэдэхүй - сурталчилгаа, эрдэм шинжилгээний өгүүллийг хэвлэж, нийтийн хүртээл болгох явдал юм.

ОУСХ ийн Орос судлалын салбарын сүүлийн үеийн судалгаанаас дурьдвал:

-“Монгол орны гадаад орчны шинэчлэл: ОХУ, БНХАУ ЫН хөгжлийн стратеги - 2020" сэдэвт томоохон ажлыг хийж гүйцэтгэсэн байна. Үүнд 2020 он хүртэлх хөрш хоёр орны урт хугацааны хөгжлийн стратегийн баримт бичигт задлан шинжилгээ хийжээ. Тухайлбал, 2008 оны 11 дүгээр сард ОХУ ын Засгийн газраас баталсан “ОХУ ын 2020 он хүртэлх нийгэм-эдийн засгийн урт хугацааны хөгжлийн үзэл баримтлал" баримт бичгийн үндсэн чиглэлүүд болох эдийн засаг, гадаад бодлого, инновацийн бодлого, Оросын нийгмийн бодлого зэрэг үндсэн асуудлыг нарийвчлан авч үзсэн байна.

-Монголын судлаачид ОХУ ын мэргэжил нэгт нөхөдтэй нягт хамтран ажиллаж байна.Энд хэд хэдэн амжилттай жишээг дурьдаж болно.Эхнийх нь Монголын ШУА ийн ОУСХ, Оросын ШУА ийн Москва дахь Дорно Дахины Хүрээлэнгийн эрдэмтэд хамтарсан судалгааны төсөл хэрэгжүүлж, МонголОросын харилцааны асуудлаар хоёр томоохон хамтын бүтээл 5/ гаргав.

- Сибирийн Монгол судлалын нэртэй төв болсон Эрхүу, УлаанҮдийн эрдэмтэдтэй хамтын ажиллагаа амжилттай өрнөж байна. Монгол Улсын БШУЯам, ШУА ийн Түүхийн хүрээлэн, ОУСХ , нөгөө талаас ОХУ ын БШУЯам, Өвөр Байгалийн Эдийн засаг Бизнесийн Их Сургууль хамтарсан төсөл хэрэгжүүлж , 2013 онд эхний үр дүн болгон "ХIX$\mathrm{XX}$ зууны зааг үеийн Орос Монголын харилцаа Эдийн засаг Дипломат ёс Соёл" нэртэй том хэмжээний хамтын бүтээл хэвлүүлэв. Энэхүу эрдэм шинжилгээний өгүүллийн эмхтгэлд $\mathrm{XX}$ зууны эхний 25 жилийн түүх, улс төр, дипломат ёс, эдийн засаг, соёл зэрэг олон чиглэлийг хамарсан судалгаа багтжээ. Үүний дараагийн боть нь түүхийн архивын баримт бичгийн эмхтгэл болон хэвлэгдэх юм.

- ОХУ ын Буриадын Их сургуулийн эрдэмтэд ОУСХ ийн мэргэжил нэгт нөхөдтэй хамтран “Оросууд Монголд эргэж ирсэн нь: загвар ба төсөөллүүд" нэртэй төсөл хэрэгжүүлж, 2014 оны 2 дугаар сард Улаанбаатар хотноо төслийн үр дүн болсон -“Орчин үеийн МонголОросын харилцаа:загвар ба төсөөллүүд” хамтын бүтээлийн нээлтийг хийв.

- ОУСХ ийн Орос ба Хятад судлалын салбарын эрдэмтэд хамтран эдүгээ “Монгол Улс дахь Орос Хятадын ашиг сонирхлын тулгамдсан асуудлуудын судалгаa/XX зууны эхнээс одоо үе хүртэл/"томоохон дэд сэдвийн судалгаа хийж байна. Сүүлийн жилүүдэд Орос ба Хятад судлалын эрдэмтэд хөрш хоёр орны судалгааг хийдэг тусдаа хийдэг аргаa өөрчилж, тодорхой асуудлаар хамтарсан судалгаа 
хийж байна. Энэ нь Монгол Улсын хоёр хөрштэй харилцах асуудлыг илүҮ цогц, прагматик, харьцуулсан байдлаар авч үзэх боломжийг өгч байгаагаар шинэлэг юм. Орчин үеийн даяаршилын үйл явц нь аливаа улс орон өөрийн гадаад орчинд гарч буй бодит өөрчлөлтийг цаг тухайд нь нарийн мэдэрч, улс төрийн бодлогодоо түргэн хувьсаж буй дэлхий ертөнцийн шинэ хандлага, өөрчлөлт хөдөлгөөн, олон талт хүчин зүйлийн харилцан нөлөөллийг соргогоор тусгахыг шаардаж байна.

-Монгол, Орос , Хятад 3 орны олон улсын харилцааны чиглэлээр мэргэшсэн эрдэмтэд харилцан мэдээлэл, туршлага солилцох зорилгоор гурван орны эрдэмтэдийн хамтарсан чуулганыг Монголын талын санаачилгаар анх 2008 оноос зохиож эхэлсэн ба эдүгээ энэ индэр нь хамтын ажиллагааны үр дүнтэй механизм болж төлөвшив. 2013 оны намар Монгол Улсын Ерөнхий сайд Н.Алтанхуягийн ивээл дор 3 орны эрдэмтэдийн 4 дахь чуулган “ Ногоон хөгжил - XXI зууны гурван талт хамтын ажиллагааны тэргүүлэх чиглэл" судвээр Улаанбаатар хотноо болсон бол саявтархан 2014 оны 5 дугаар сарын 30 нд Бээжин хотноо “Зүүн Хойд Азийн хамтын ажиллагааны хэтийн төлөв” сэдвээр 5 дахь чуулган амжилттай болов.

Өнөөгийн шатан дахь Орос судлалын тулгамдсан зорилтууд гэвэл:

-Орон судлал, ОХУ ын гадаад, дотоод бодлогын асуудлаар цогц судалгааг эрчимжүүлэх, бага судлагдсан асуудалд илүүтэй төвлөрөх, судалгааны арга зүйд хэвшиж тогтсон “хөрш орны” хэмжүүрээс татгалзах

-Глобаль болон бүс нутгийн хандлагыг уялдуулах зарчмыг судалгаанд тусгах, шинжлэх ухааны төслийн боловсруулалтын гол шаардлага болсон улс төрийн нөлөөллөөс ангид байж, Орос судлалын олон талт чиглэлүүдэд гүнзгий дүн шинжилгээ хийх хандлагыг голлон баримтлах

-Орос судлалын салбарт шинэ үеийн залуу халааг бэлтгэх, Орос судлалаар мэргэшсэн гадаад орны нэртэй төв, ТББ, эрдэмтэдтэй мэдээлэл, туршлага солилцох зорилгоор идэвхтэй хамтран ажиллах зэрэг юм.

Ашигласан бүтээлийн жагсаалт

1. ”Орос дахь монгол угсааны улсууд”. Улаанбаатар, 1995, Ч.Батцэцэг “ОХУ ын БНБуриад улс". Улаанбаатар, 1996 , А.Нямдолжин “ ОХУ ын Ази, Номхон далайн бүс нутагт явуулж буй гадаад бодлого”. Улаанбаатар, 1999

2. Б.Лхамсүрэн “Монголын гадаад орчин, төрийн тусгаар тогтнол.” Улаанбаатар, 1995, Б.Балдоо, С.Дамдинсүрэн, Л.Хайсандай “Монголын тусгаар тогтнол ба Орос, Хятадын хүчин зүйл” Улаанбаатар, 1999, С.Дамдинсүрэн “Монголын тусгаар тогтнол: эрин зууны баталгаажилт". Улаанбаатар, 2001, К.Дэмбэрэл “Влияние международной среды на Монголию” Иркутск, 2002, Б.Балдоо “Монгол Улсын гадаад харилцаа. XX зууны эхэн ба төгсгөл үе”. Улаанбаатар, 2003

3. "Монгол - Оросын харилцаа: бүсчилсэн хөгжлийн бодлого, хамтын ажиллагаа" хамтын бүтээл Улаанбаатар, 2005, “ОХУ ын бүс нутгаа хөгжүүлэх бодлого ба Монгол-Оросын харилцаa/ XX-XXI з ууны заагт". Улаанбаатар, хамтын бүтээл

4. О.Батсайхан "Монголын тусгаар тогтнол ба Хятад, Орос, Монгол гурван улсын Хиагтын гэрээ”/1911 - 1916/. Улаанбаатар, 2002, “Монгол үндэстэн бүрэн эрхт улс болох замд” /1911 - 1946/. Улаанбаатар, 2005

5. "Россия и Монголия: новый взгляд на взаимоотношения в XX веке". Москва, 2001, “Россия и Монголия на пути к стратегическому партнерству”/1990 -2005/. Москва,ИВ РАН, 2001, “Монгол-Оросын харилцаа баримт бичгүҮд /1991-2004/. Улаанбаатар, 2004 хамтын бүтээл 